\title{
Microenzyme-linked immunosorbent assay for the detection of specific IgM antibodies in human
} syphilis

\author{
E-G LINDENSCHMIDT,* R LAUFS,* AND F MÜLLER† \\ From the *Institute of Medical Microbiology and Immunology, University of Hamburg, Hamburg; the \\ †Division of Serology, Department of Medical Microbiology, Institute of Hygiene, Hamburg, West \\ Germany
}

SUMMARY An enzyme-linked immunosorbent assay (ELISA) using a highly purified soluble antigen prepared from pathogenic Treponema pallidum (Nichols) was carried out to detect specific IgM antibodies in syphilis. Serum specimens from 365 patients with untreated or treated syphilis were tested by the ELISA and by the 19S(IgM) fluorescent treponemal antibody-absorbed test. In the ELISA sera were preabsorbed with aggregated human IgG to eliminate any rheumatoid factor present. Sera from 331 healthy blood donors served as controls. The results of both tests correlated well. The specificity and sensitivity of the treponemal ELISA were both $>97 \%$. The assay was easy to perform and may be automated.

\section{Introduction}

The demonstration of specific IgM antibodies is of diagnostic importance in several infectious diseases and may influence decisions regarding the necessity of treatment. The presence of this type of antibody in the sera of neonates and adults may be an indication of the persistence of treponemes within the body 12 and also of whether or not treatment is necessary. ${ }^{3-8}$

The 19S(IgM) fluorescent treponemal antibodyabsorbed (FTA-ABS) test has been used to detect treponemal IgM antibodies. ${ }^{4-9}$ The results of this test correlated well with the clinical features of untreated syphilis at the various stages. ${ }^{48}$ Furthermore, the test provided information on the need for treatment in most patients with latent or late latent infections when details of preceding treatment were lacking. ${ }^{48}$ Though several studies have shown the high specificity and sensitivity of the 19S(IgM)-FTAABS test, 911 the test requires special equipment and is therefore not suitable for routine purposes. For this reason, a technically simpler method with a specificity and sensitivity comparable with the 19S(IgM)-FTA-ABS test is needed. Since these conditions are only partly fulfilled by the 19S(IgM)

\footnotetext{
Address for reprints: Dr E-G Lindenschmidt, Institute of Medical Microbiology and Immunology, University of Hamburg, Martinistrasse 52, D-2000 Hamburg 20, Federal Republic of Germany
}

Accepted for publication 18 December 1982
Treponema pallidum haemagglutination assay (TPHA) and the IgM solid-phase haemadsorption assay (SPHA), ${ }^{10}$ we decided to assess the effectiveness of the enzyme-linked immunosorbent assay (ELISA) in detecting treponemal IgM antibodies by comparing its results in the sera of patients with syphilis and healthy controls with those of the 19S(IgM)-FTA-ABS test. From these data we calculated the specificity and sensitivity of the IgMTP-ABS ELISA. Moreover, since the use of an appropriate antigen is an important factor in the development of an ELISA for the diagnosis of syphilis we prepared a highly purified soluble antigen from homogenates of pathogenic $T$ pallidum.

\section{Material and methods}

SELECTION AND STORAGE OF SERA

On the basis of the clinical features or history of infection (and its treatment), summarised in a standard proforma, serum specimens from 365 patients with syphilis were divided into: $(a)$ those with untreated or inadequately treated primary syphilis $(n=54)$; $(b)$ those with untreated secondary syphilis $(n=85) ;(c)$ those with tertiary syphilis (but no clinical features of neurosyphilis) $(n=30) ;(d)$ those with a doubtful history of infection and inadequate treatment $(n=79)$; and $(e)$ those with adequately treated syphilis $(n=117)$. Clinical data were provided by dermatologists and neurologists at 
hospitals in the district of Hamburg. In addition, 321 sera from healthy blood donors were included as controls. All serum samples were pretested for treponema-specific antibodies by the TPHA and the FTA-ABS test. Sera from untreated or inadequately treated patients were reactive in the TPHA, the FTAABS, and the 19S(IgM)-FTA-ABS test and those from adequately treated patients reactive in the TPHA and the FTA-ABS test but non-reactive in the 19S(IgM)-FTA-ABS test. The sera of the blood donors were non-reactive in the TPHA and the FTAABS test and were not examined by the 19S(IgM)-FTA-ABS test. Heating the sera (at $56^{\circ} \mathrm{C}$ for 30 minutes) and storing them at $4^{\circ} \mathrm{C}$ for more than 48 hours were avoided since they reduce or eliminate specific IgM antibody activity. ${ }^{6}$ The specimens were, therefore, tested within 24 hours of storage at $4^{\circ} \mathrm{C}$ at the latest or after preservation at $-70^{\circ} \mathrm{C}$ until use.

PREPARATION OF A SOLUBLE TREPONEMAL ANTIGEN FOR THE ELISA

A suspension of $T$ pallidum (pathogenic Nichols strain) at a concentration of $\geqslant 1 \times 10^{8} / \mathrm{ml}$ was homogenised by ultrasonication. ${ }^{12}$ The homogenate was cleared of particulate matter by low speed centrifugation (3000 $\times \mathrm{g}$ for 20 minutes). The supernatant was layered on a discontinuous $\mathrm{CsCl}$ gradient (density $1 \cdot 05-1 \cdot 45$ ) and centrifuged in a SW-50 rotor of a Beckman L5-50 B ultracentrifuge at $40000 \times g$ for 90 minutes at $4^{\circ} \mathrm{C}$. Drop fractions of about $250 \mu \mathrm{l}$ total volume were tested for antigenicity by the ELISA technique using a serum which contained treponema-specific 19S(IgM) antibodies at a titre of $\geqslant 300$. Fractions 4 and 5 of the gradient, which usually contain the most soluble antigen, were subjected to a second density gradient centrifugation step. Recentrifugation produced fractions 4 and 5 in the highly purified treponemal antigen. After dialysis against phosphate-buffered saline (PBS) the antigen was stored at $4^{\circ} \mathrm{C}$ until use.

ESTIMATION OF PROTEIN, POLYSACCHARIDES, AND LIPIDS IN THE ANTIGEN

Protein concentrations were determined according to the method of Lowry et al. ${ }^{13}$ Polysaccharides were detected by SDS-polyacrylamide gel electrophoresis ${ }^{14}$ and periodic acid-silver staining. ${ }^{15}$ Triglycerides were estimated by an enzymatic method (Boehringer, Mannheim, FRG).

\section{ELISA PROCEDURE}

Cups of polyvinyl microtitre plates were filled with $100 \mu \mathrm{l}$ of antigen diluted in isotonic bicarbonate buffer (pH 9.6) and incubated for 18 hours at $4^{\circ} \mathrm{C}$ to allow adsorption to the solid phase. Before the test the cups were washed three times with $0.05 \%$ Tween 20-PBS.

After the absorption procedure (see below) the sera were diluted with PBS containing bovine serum albumin $(0.1 \% \mathrm{w} / \mathrm{v})(0.1$ BSA-PBS) and tested at dilutions of $1 / 50,1 / 100,1 / 400$, and $1 / 1000$. One hundred microlitres of each dilution were pipetted into the antigen-coated cups and incubated for 90 minutes at room temperature. After this first immunoreaction the cups were washed three times with $0.05 \%$ Tween 20 -PBS.

Antibodies coupled to the treponemal antigen were identified by incubation for two hours at room temperature with horseradish peroxidase (HRPO)labelled anti-human-IgM serum. The labelling of the anti-human-IgM serum was carried out with HRPO (Sigma, type IV) according to the method of Wilson and Nakane. ${ }^{16}$ The last washing was performed with $0.5 \%$ of Tween 20-PBS.

The enzyme reaction was performed with $50 \mu \mathrm{l}$ substrate solution $(10 \mathrm{mg}$ o-phenylenediamine dissolved in $10 \mathrm{ml} 0.1 \mathrm{~mol} / 1$ phosphate buffer, $\mathrm{pH}$ $6 \cdot 0$, containing $0.01 \%$ hydrogen peroxide) for 10 minutes in the dark and stopped by the addition of $100 \mu 12 \mathrm{~mol} / 1$ sulphuric acid. The cups were read photometrically at $492 \mathrm{~nm}$ in an automatic multiscan (Titertek) against a blank of $50 \mu \mathrm{l}$ substrate solution and $100 \mu \mathrm{l}$ sulphuric acid. Optical densities of the test sera which exceeded five standard deviations of the arithmetic mean of eight negative controls (containing aggregated IgG) were considered to be reactive.

ABSORPTION OF SERA BEFORE THE ELISA

Immediately before the assay was carried out sera were incubated with TPHA absorbing diluent (Fujizoki Pharmaceuticals, Tokyo, Japan) for 30 minutes at room temperature. After this first absorption step an equal volume of heat-aggregated human IgG $(5 \mathrm{mg} / \mathrm{ml})$ was added to all serum dilutions to eliminate possible rheumatoid factor present in the sera. ${ }^{17}$ In addition, a second test dilution of 1/50 was prepared without human IgG to indicate whether rheumatoid factor was present or not. Only test dilutions after treatment with aggregated IgG were included in the results.

FRACTIONATION OF SERA BY GEL FILTRATION The micromethod of Muller and Oelerich ${ }^{18}$ was used: $0.7 \mathrm{ml}$ serum was passed through a $1.5 \times 14 \mathrm{~cm}$ Ultrogen AcA 34 column using PBS at pH 7.3 and a pressure of $30 \mathrm{~cm}$ of fluid in about 25 minutes. Every 20 drops (approximately $1.3 \mathrm{ml}$ ) of the eluate were collected as a fraction. 
19S(IgM)-FTA-ABS TEST PROCEDURE

The method has been described. 9 $T$ pallidum (pathogenic Nichols strain) from the testes of infected rabbits was used as antigen. For the detection of antibodies affixed to the antigen an FITC-labelled antihuman-IgM rabbit serum with $\mu$-chain specificity (Dako Immunochemicals, Copenhagen, Denmark) was used at a final dilution of $1 / 50$.

19S(IgM) antibodies normally eluate in the first three to five fractions of the descending part of the first elution peak. The first three fractions were absorbed with an equal volume of a concentrated ultrasonicate of Treponema phagedenis (Reiter strain; F Hoffmann-LaRoche, Basel, Switzerland). Fractions diluted with PBS and treated in the same manner were prepared as controls. ${ }^{6}$

\section{Results}

\section{CHARACTERISTICS OF THE SOLUBLE}

\section{TREPONEMAL ANTIGEN}

Fifteen batches of soluble treponemal antigen were prepared and tested for activity and specificity with the ELISA; for technical reasons three of these were unsuitable. The results of the density gradient centrifugation of one of the antigen preparations are shown in fig 1. The two curves show that after the second centrifugation step the soluble antigen in the zone of density at 1.05 (fractions 4 and 5) was purified of high-molecular weight antigenic components (fractions 16 and 17).

On the basis of more than 1200 assays performed with a working dilution of fraction 4 as the antigen and antibody-free sera, the mean optical density at $492 \mathrm{~nm}$ at the end of the enzyme reaction was $\leqslant 0 \cdot 2$. Quantitative experiments with positive controls showed a high activity of the antigen. As determined

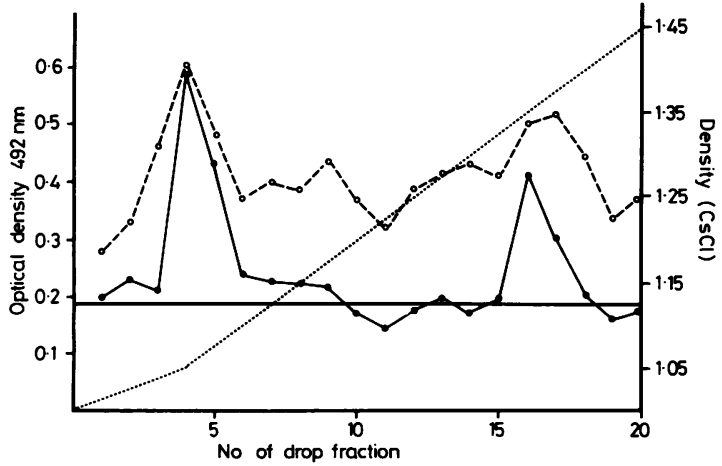

FIG 1 Separation and purification of a treponemal antigen by two $\mathrm{CsCl}$ density gradient centrifugation steps: $\bigcirc--\longrightarrow$ first; $\bullet-\bullet$ second; ..... density. by a serum sample which contained treponemal IgM antibodies at a titre of $\geqslant 300$, the 12 suitable batches were diluted $1 / 10^{-3}$ to $1 / 10^{-5}$ for test purposes.

After storage of the antigen for more than eight weeks at $4^{\circ} \mathrm{C},-20^{\circ} \mathrm{C}$, and even $-70^{\circ} \mathrm{C}$, the basic extinction at $492 \mathrm{~nm}$ at the end of the ELISA rose for unknown reasons. Chemical analysis of fraction 4 from three different batches showed that it consisted mainly of protein with small amounts of lipids and polysaccharides. A quantitative analysis of the components was not performed.

\section{SPECIFICITY AND SENSITIVITY OF THE ELISA}

The reactivity of the sera from the patients and controls to the three tests are summarised in table I. The specificity and sensitivity of the ELISA were calculated according to table II. In six of the 117 patients with adequately treated syphilis and three of 321 healthy blood donors the ELISA was reactive in contrast to non-reactive results in the 19S(IgM)-FTAABS test. This resulted in a specificity of the assay of $\mathrm{D} / \mathrm{D}+\mathrm{C}=>97 \%$ (table II).

In the sera of 169 patients with untreated or inadequately treated primary, secondary, or tertiary syphilis both the ELISA and the 19S(IgM)-FTA-ABS test were reactive. In the patients with untreated

TABLE I Reactivity of 365 patients with syphilis and 321 controls to the three different tests used to detect treponemal antibodies

\begin{tabular}{|c|c|c|c|c|}
\hline \multirow[b]{2}{*}{ Diagnostic category } & \multirow[b]{2}{*}{$\begin{array}{l}\text { No of } \\
\text { patients }\end{array}$} & \multicolumn{3}{|c|}{ No with sera reactive to: } \\
\hline & & $E L I S A$ & $\begin{array}{l}\text { ISS }(I g M)- \\
F T A-A B S\end{array}$ & $\begin{array}{l}T P H A \text { and } \\
F T A-A B S\end{array}$ \\
\hline $\begin{array}{l}\text { Primary syphilis } \\
\text { Secondary syphilis } \\
\text { Tertiary syphilis } \\
\text { Latent syphilis } \\
\text { Adequately treated }\end{array}$ & $\begin{array}{l}54 \\
85 \\
30 \\
79\end{array}$ & $\begin{array}{l}54 \\
85 \\
30 \\
73\end{array}$ & $\begin{array}{l}54 \\
85 \\
30 \\
79+\end{array}$ & $\begin{array}{l}53 * \\
85 \\
30 \\
79\end{array}$ \\
\hline $\begin{array}{l}\text { syphilis } \\
\text { Healthy blood donors }\end{array}$ & $\begin{array}{l}117 \\
321\end{array}$ & $\begin{array}{l}6 \\
3\end{array}$ & $\begin{array}{l}0 \\
\ddagger\end{array}$ & $\begin{array}{r}117 \\
0\end{array}$ \\
\hline
\end{tabular}

*Serum from patient was non-reactive at the standard dilution of the TPHA $(1 / 20)$ but reactive in the FTA-ABS test.

tRate of error of the 19S(IgM)-FTA-ABS was about $3 \%$ \#ot done but considered to be non-reactive.

ELISA = enzyme-linked immunosorbent assay; FTA-ABS = fluorescent treponemal antibody-absorbed (test); TPHA = $T$ pallidum haemagglutination assay

TABLE II Sensitivity and specificity of treponemal ELISA compared with the 19S-IgM-FTA-ABS test

\begin{tabular}{llr}
\hline & ELISA & No of sera \\
\hline 19S-IgM-FTA-ABS test & & \\
A: Reactive & + & 242 \\
B: Reactive & - & 6 \\
C: Non-reactive & + & 9 \\
D: Non-reactive & - & 429 \\
\hline
\end{tabular}

$+=$ Reactive; $-=$ non-reactive 
latent syphilis the ELISA was reactive in only 73 of 79 cases. This resulted in a sensitivity of the assay of $\mathrm{A} / \mathrm{A}+\mathrm{B}=>97 \%$ (table II).

\section{COMPARISON OF ANTIBODY TITRES BY THE}

ELISA AND THE 19S(IgM)-FTA-ABS TEST

The titres of specific IgM antibodies as detected by the ELISA and the 19S(IgM)-FTA-ABS test in the sera of 242 patients with syphilis are compared in table III. In $194(80 \%)$ sera the titres correlated within the limit of technical variation (about one dilution); $10 \%$ showed a raised or decreased titre in one of the assays. Five sera with specific IgM antibody at a titre of $\geqslant 400$ in the ELISA were reactive only at this high dilution but non-reactive at lower dilutions.

TABLE III Antibody titres in the treponemal ELISA compared with those in the 19S-IgM-FTA-ABS test

\begin{tabular}{llllll}
\hline \multirow{2}{*}{$\begin{array}{l}\text { 19S(IgM) } \\
\text { FTA-ABS } \\
\text { (dilutions) }\end{array}$} & $\begin{array}{l}\text { No of sera } \\
(n=242)\end{array}$ & $\begin{array}{l}\text { No of sera positive in the ELISA } \\
\text { at (dilutions): }\end{array}$ \\
\cline { 3 - 7 } & $1 / 50$ & $1 / 100$ & $1 / 400$ & $\geqslant 1 / 1000$ \\
\hline $1 / 10-1 / 20$ & 23 & 13 & 7 & $3^{*}$ & 0 \\
$1 / 40$ & 48 & 23 & 22 & 3 & 0 \\
$1 / 80$ & 55 & 15 & 30 & 10 & 0 \\
$1 / 160$ & 60 & 6 & 33 & 19 & $2^{*}$ \\
$\geqslant 1 / 320$ & 56 & 1 & 14 & 32 & 9 \\
\hline
\end{tabular}

*Antibodies detected by the ELISA only at higher serum dilutions (prozone)

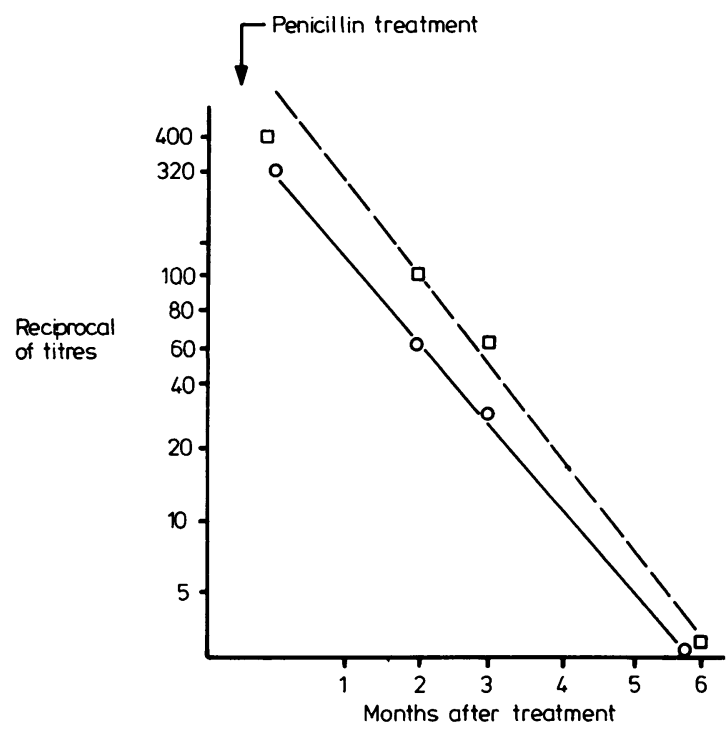

FIG 2 Decrease of IgM antibody titres after penicillin treatment of tertiary syphilis: $\square---\square E L I S A$; $\bigcirc-\bigcirc 19 S(I g M)-F T A-A B S$
INFLUENCE OF PENICILLIN TREATMENT ON IgM ANTIBODY TITRES

In eight patients specific IgM antibody titres were determined after penicillin treatment. The decrease in titres and finally the resolution of treponemal IgM antibodies in a patient treated for tertiary syphilis are shown in fig 2 . The curves of the two assays showed reliable correlation.

\section{EFFECT ON SERUM ABSORPTION WITH AGGREGATED HUMAN IgG}

After the addition of aggregated human IgG before the ELISA 52 of $365(14 \%)$ serum specimens (dilution 1/50) showed a reduction in optical density at $492 \mathrm{~nm}$ of more than $10 \%$ compared with those of the controls without preabsorption. Thirty-two sera were tested for rheumatoid factor; of these, 28 were reactive in the latex and the Rose-Waaler tests thus confirming the presence of rheumatoid factor.

\section{Discussion}

In looking for a suitable alternative to the technically complicated 19S(IgM)-FTA-ABS test in detecting treponemal IgM antibodies in human syphilis the ELISA seemed to be worth investigating. Veldkamp and Visser ${ }^{19}$ and Pope et apo recommended the ELISA for demonstrating specific IgG antibodies in syphilis; both groups used a crude antigen from homogenised $T$ pallidum.

In preliminary investigations we found that crude antigens extracted from treponemal homogenates were not suitable for the detection of IgM antibodies with the ELISA, since a non-specific enzyme reaction occurred with optical densities at $492 \mathrm{~nm}$ of $>0.5$ in sera from control subjects. Furthermore, reactivity was achieved only if at least $50 \mu \mathrm{g}$ antigen protein was applied to the solid phase of the cups for adsorption (unpublished data). Thus we concluded that the purity of the antigen to be absorbed to the solid phase was of great importance. For this reason we prepared a purified soluble antigen with high activity from pathogenic $T$ pallidum. This induces only a low basic extinction in the ELISA after enzyme reaction when used on sera from control subjects and may be used in high dilution.

After two identical purification steps in the $\mathrm{CsCl}$ density gradient ultracentrifugation of crude homogenate from pathogenic $T$ pallidum an antigen fraction was obtained which was free of high molecular weight components. The fraction 4 of the gradient was a mixture of low molecular weight treponemal antigens. It contained chiefly protein but also small amounts of polysaccharides and lipids. The preparation had high antigenic activity and 
could be used in the ELISA at dilutions of $1 / 10^{-3}$ to $1 / 10^{-5}$. At $4^{\circ} \mathrm{C}$ the antigen was stable for 6-8 weeks; thereafter the antigenic activity diminished.

If rheumatoid factor and group-specific treponemal antibodies were eliminated previously from the specimens by absorption, the detection of antibodies with the ELISA was specific at a serum dilution of $1 / 50$. In control experiments with sera from adequately treated patients with syphilis and healthy blood donors the specificity of the assay was $>97 \%$; the ELISA results were comparable with those of the 19S(IgM)-FTA-ABS test.

In our present studies the treponemal ELISA was reactive in all cases of primary syphilis. Only in patients with untreated latent syphilis was there a difference in the results of the 19S(IgM)-FTA-ABS test and ELISA. From these results the sensitivity of the ELISA was calculated to be $>97 \%$-that is, in the same range as that of the 19S(IgM)-FTA-ABS test.

When the antibody titres obtained by the ELISA and the 19S(IgM)-FTA-ABS test are compared, there was a correlation of about $80 \%$. The deviation of $\pm 10 \%$ in correlation was probably technical in origin, and therefore no conclusions on the higher sensitivity of one or other assay may be drawn. The parallel decrease of antibody titres in patients after penicillin treatment should be similiarly interpreted.

Five of the sera reactive in the 19S(IgM)-FTA-ABS test were non-reactive at the lower serum dilutions in the ELISA. In the ELISA the IgM antibody was present only in serum diluted $1 / 400$ or $1 / 1000$; this may have been due to a prozone phenomenon. ${ }^{21-23}$ In contrast to the recommendations of Veldkamp and Visser ${ }^{19}$ the assay should be performed quantitatively for diagnostic purposes-that is, at at least four dilution steps up to a dilution of $1 / 1000$.

The preabsorption of serum specimens with aggregated human IgG was most important. By comparing the results before and after absorption interference by rheumatoid factor could be shown in $14 \%$ of the samples studied. Several investigators have found rheumatoid factor in the sera of patients with syphilis. ${ }^{62427}$

Competitive inhibition of IgM by IgG antibodies of the same specificity was not observed in the ELISA. In 17 serum samples of patients with secondary syphilis and specific IgG antibody titres of 10000 , as detected by the ELISA, the reactivity in the ELISA was not influenced. A discrimination between $19 S(\operatorname{IgM})$ and $8 \mathrm{~S}(\operatorname{IgM})$ antibodies is not, however, possible by this assay. 8S(IgM) treponemal antibodies occur rarely, mainly in chronic syphilis. ${ }^{28}$ Only a few doubtful cases therefore need to be retested for $8 \mathrm{~S}(\mathrm{IgM})$ antibodies by an appropriate separation technique. The assay was reproducible.
These results suggest that the IgM-TP-ABSELISA provides reliable information on the presence of IgM antibodies in the early stages of syphilis and during the course of infection as well as their absence after adequate treatment. An advantage of the test is its ability to be automated.

\section{References}

1. Franklin EC. Structure and function of immunoglobulins. $N Y$ J Med 1968; 68:411-22.

2. Bienenstock J, Bloch $\mathbf{K J}$. Some characteristics of human conglutinin. J Immunol 1966;96:637-45.

3. Muller F, Sinzig G. Specificity and sensitivity of immunological diagnosis of congenital neonatal syphilis by the 19S(IgM)-FTA-ABS test. Zeitschr Hautkr 1982;57:983-1001.

4. Herbst B-R, Goerz G, Muller F. Diagnostischer und therapeutischer Aussagewert des IgM-FTA-ABS- und IgMFTA-19S-Tests bei der Syphilis. Aktuel Dermatol 1975;5: 175-83.

5. Luger A. Syphilis. In: Korting GW, ed. Dermatologie in Praxis und Klinik, Vol IV. Stuttgart and New York: Thieme. 1981; $1-79$.

6. Muller F. The 19S(IgM)-FTA-ABS test in the serodiagnosis of syphilis. Technique, sources of error and diagnostical information of results. Immun Infekt 1982; 10:23-34.

7. Schmidt B. The 19S-IgM-FTA-ABS test in the serumdiagnosis of syphilis. WHO/VDT/RES/79.362. Geneva: WHO, 1979.

8. Muller F, Oelerich S. Korrelation immunologischer Parameter zu den Stadien der apparenten und klinisch stummen Syphilis. Dermatol Monatsschr 1979; 165:385-95.

9. Muller F. Zur Technik des Nachweises treponemenspezifischer 19S-IgM-Antikorper bei der latenten und spatlatenten Syphilis. Immun Infekt 1977; 5: 109-13.

10. Muller F, Lindenschmidt E-G. Demonstration of specific 19S(IgM) antibodies in untreated and treated syphilis. $B r J$ Vener Dis 1982;58:12-7.

11. Luger A, Schmidt BL, Schonwald E. Die SPHA-Technik (solid-phase haemadsorption) in der Syphilisserologie. Einjăhrige Erfahrung im Routinebetrieb. Hautarzt 1982; 33: $133-44$.

12. Lindenschmidt E-G, Muller F. A treponema-specific soluble antigen for an IgM and IgG-TP-ABS-ELISA and its application for the serodiagnosis of syphilis. WHO/ VDT/RES/81.369. Geneva: WHO, 1981.

13. Lowry OH, Rosenbrough NJ, Farr AL. Protein measurement with the folin phenol reagent. J Biol Chem 1961; 193:265-75.

14. Laemmli UK. Clearage of structural proteus during the assembly of the head of bacteriophage $T_{4}$. Nature 1970; 227:680-5.

15. Dubray G, Bezard G. A highly sensitive periodic acid-silver stain for 1,2-diol groups of glycoproteines and polysaccharides in polyacrylamide gels. Ann Biochem 1982;119:325-9.

16. Wilson MB, Nakane PK. Recent developments in the periodate method of conjugating horseradish peroxidase to antibodies. In: Knapp W, Holubar K, Wick G, eds. Immunofluorescence and related staining techniques. Amsterdam: North Holland Biomedical Press. 1978;115-24.

17. Chirodaria PV, Fraser KB, Standford F. Secondary fluorescent staining of virus antigens by rheumatoid factor and fluorescein-conjugated anti-IgM. Ann Rheum Dis 1968; 32:53-8.

18. Muller F, Oelerich S. Ein modifiziertes Verfahren des IgMFTA-19S-Tests zum Nachweis kompetitiv gehemmter Antikorper bei der Syphilis. Das Ärtl Laboratorium 1978; 24:386-91.

19. Veldkamp J, Visser AM. Application of the enzyme-linked immunosorbent assay (ELISA) in the serodiagnosis of syphilis. Br J Vener Dis 1975;51:227-31.

20. Pope V, Hunter EF, Feeley JC. Evaluation of the microenzyme-linked immunosorbent assay with Treponema pallidum antigen. J Clin Microbiol 1982;15:630-4.

21. Roggendorf M, Deinhardt F, Frossner GG, Scheid G, Bayerl $\mathbf{B}$, Zachoval $\mathbf{R}$, Immunoglobulin $\mathbf{M}$ antibodies to hepatitis $\mathbf{B}$ core antigen: evaluation of enzyme immunoassay for diagnosis of hepatitis B virus infection. J Clin Microbiol 1981; 13:618-25. 
22. Grippenberg $M$, Nissinen $A$, Văsănen $E$, Linder $E$. Demonstration of antibodies against Yersinia enterocolitica lipopolysaccharides in human sera by enzyme-linked immunosorbent assay. J Clin Microbiol 1979; 10:279-84.

23. Leiniki PO, Passila S. Solid phase antibody assay by means of enzyme conjugated to anti-immunoglobulin. J Clin Pathol 1976; 29: 1116-20.

24. O'Neill P. A new look at the serology" of treponemal disease. Br J Vener Dis 1976; 62:296-9.

25. Reimer CB, Black CM, Phillips DJ, et al. The specificity of fetal IgM: antibody or anti antibody? Ann NY Acad Sci 1975; $254: 77-93$. 